\title{
The Problems of Imposing Special Terms and Conditions for Land and Forest Use in Lithuania
}

\author{
Lina Papšienè, Irina Jonauskienè \\ Vilnius Gediminas Technical University, Sauletekio al. 11, Vilnius 10223, Lithuania
}

\begin{abstract}
In addition to the general ecological requirements laid down in the Republic of Lithuania Law on Environmental Protection land parcels are subject to special conditions for land and forest use. These ensure rational use of natural resources as well as safe and healthy living and working environment. Imposing these conditions, therefore, has, at all times, been a topical issue. The article analyses cases of imposing the special conditions, procedures for entering the same in the data base of the Real Property Cadastre and Register, their cartographic representation, as well as providing and updating necessary spatial data in Lithuania. Furthermore, concerning the special restrictions on land and forest use, it gives an overview of data relations to the territorial planning, cadastral surveying and identification of cadastral data. Finally, the article discusses the problems of data update in relation to imposing the special conditions and offers possible solutions.
\end{abstract}

Keywords: special conditions for land and forest use; environmental protection; spatial data; Real Property Cadastre.

\section{Introduction}

The optimal usage and administration of the underground resources is significant for the whole world. Therefore, when planning the territories in accordance with the principals of the harmonious society and when landscaping the individual land parcels it is required to determine the special terms and conditions for the land use as well as restrictions, to be able to ensure the surveillance of the compliance of these restrictions. In Lithuania, special terms and conditions of land use together with the restrictions are determined in accordance with the prescribed Law on the Environment, Law on the Protected territories, Law on Territory Planning, Law on Land, Law on Forest, Water Act, Reclamation Law, Law on Immovable Cultural Heritage Protection and the other legal acts. The special terms and conditions as well as restrictions, properly identified ensure safe and healthy residential environment, habitat, and rational usage of the underground resources. The establishment of these conditions and terms as well as restrictions is a subsidiary measure for the prevention of accidents when performing the agricultural activities and works, for the avoidance of the possible flooding, for the induced risks caused by the landslides and karsts phenomena. The sanitary protection zones (SPZ), determined correctly and the protection zones (PZ) could prevent the spread of diseases caused by animals, the spreading of accidental situations caused by industrial and energy systems as well as their negative effect circulation. They could prevent the risk of fire or vehicle accident or the criminal activities at the border, could reduce the possible negative effect of the vehicles, industry, laundries and the other facilities on to the citizens or nature targets. The nonconformity of the special terms and conditions and restrictions of land use causes threat to the surrounding environment, human health, the property and infrastructure, therefore, when discussing the expediency of determining these conditions as well as restrictions it is necessary to assess all the possible threats [1].

In accordance with the provisions of the Law on Environment of the Republic of Lithuania for the legal and natural persons providing the economic activities, which could have the effect onto the environment; the territorial organization and State regulation of the environment management is carried out according to the documents of the general and special territory planning [2]. They are the legal and natural persons or designers, designing the construction, reconstruction or development of the objects, that could have an effect on to the environment, those persons working out the projects of the general and special territorial planning, they all are obliged to foresee the measures, regarding the rational usage of the natural resources in the planning documentation, in order to avoid the negative effect onto the environment. The documents

Corresponding author: Irina Jonauskienè. E-mail address: irina.jonauskiene $@$ vgtu.lt

http://dx.doi.org/10.3846/enviro.2014.234

(C) 2014 The Authors. Published by VGTU Press. This is an open-access article distributed under the terms of the Creative Commons Attribution License, which permits unrestricted use, distribution, and reproduction in any medium, provided the original author and source are credited. 
of the special territory planning are such documents of the territorial planning, where according to the requirement of the territorial planning and the tasks there are determined certain activities regarding the usage, administration of the planned territories and (or) measures of protection [3].

While working on the documents of the territorial planning, the constructional documentation or the projects related to the other activities, there have to be complied with the prescribed special terms and conditions on the land use or the restrictions, prescribed by the laws or Governmental Resolutions, regulating economical and (or) the other activities [4], which depend on the geographical position of the parcel, on the adjacencies, on the main purpose of land use, on the type of land parcel usage and the particular specific activity on the land parcel, on the structures located on the land parcel, on the environment and needs of the public health protection [5].

The aim of the work, after having reviewed the regulating legal acts concerning territorial planning, land management, real estate cadastre and the analysis of the scientific publications, to isolate the problems of the special land use as well as the problems of determining the restrictions, to be able to foresee the ways of the solution of the problems.

\section{Transformations and innovations in the territorial planning system}

Lithuania as well as the majority of the post-soviet European states tends to experience the reduction of the number of the population and the tendency of aging. It also feels the lack of the methods allowing the effective administration of the urban development under the market economy conditions and the achievement of the harmonious development, taking into consideration the social, economic and environmental tasks [7]. In the Republic of Lithuania as well as in the majority of the developed countries, the development of the cities and residential areas was made spontaneously, the planning of the developed territories underwent the lack of the systematic approach to the problem, the priorities and criteria of those territories were not precisely set. The laws and the other legal acts of the Republic of Lithuania regulate the process of the territorial planning, but they do not prescribe the criteria and principals to be followed when designing. Thus, that situation impedes the decision making of the solutions related to the land use and restrictions; it does not promote the development of the infrastructure, does not make the favourable conditions for the protection of the natural karsts and for the analysis of the significant issues related to the other items of the sustainable development.

Due, to the procedure and orders, validated by January 1,2014, regarding the sequence of the territorial planning process, there were held many legal disputes; when after the approved of the general or detailed plans, there followed the additional requirements, which were determined by the special plans, because of the failures to meet the deadlines, prescribed in the legal acts on the procedures of the working out of the territorial planning, on the coordination of the plans and their approval as well as due to disregarding of the solutions of the territorial planning. The law prescribed several types of the levels regarding the territorial planning documents in accordance with the institutions approving them, in accordance with the size of the territory planned and on the level of the specified decisions. Several institutions were qualified for working out and approval of the special plans; the institutions mostly did not have enough financial resources for the preparation and implementation of the plans.

The attention was paid to the urban forums on the manifestation of the stagnancy in planning and designing procedures within the areas of the nature preservation and cultural heritage, the malpractice of the surveillance institutions causing the confrontation with the users of the territories, designers and investors [6], [8]. Due, to the long lasting territorial planning procedures, namely the information of the person concerned, the publicizing of the documents, the discussing with the society, the coordination and approval of the plans; the working out of the detailed plan for the agricultural parcel lasted from 9 months up to 3 years, therefore, the valid order made the unfavourable conditions for the investment attraction [9], did not promote the development of the infrastructure, the implementation of the environmental protection measures.

The perfection of the territorial planning process targeted to create safe and comfortable residential environment based on the principals of the harmonious development and upgrading of the business environment, attraction of the investors, expansion of the information technologies and the demographic changes made it possible to have the appropriate conditions. When upgrading the territorial planning system, the efforts are made to comprehensively upgrade and perfect the quality of the planning works; to unify the content, scope, the form of submission of the planning documents; to work out the methodological means for the territorial planning documents; legally define the content of the public interest of the society and the boundaries of its validation, the relations with the other interests, providing the required financing for the implementation of the public interest; to work out the quality assessment system of the territorial planning documents, norms of planning, methodology of the execution of monitoring; to initiate the establishment of the expert groups at the coordinating institutions [6]. The territorial planning is going to become an integral social, economical and environmental measure only after implementation of the tasks, there is going to be created a new territorial planning and construction system, ensuring the balanced and qualitative development of the territories.

Since January 1, 2014, there has come into effect a new edition of the Law of the Territorial Panning of the Republic of Lithuania, which has been prepared according to the best experience of the territorial planning systems of the following countries of the European Union such as Germany, Sweden, Denmark and Finland and which is signified by the long lasting practice and universally accepted goals of the harmonious development [9].

In accordance with the new concept of the territorial planning regulations in Lithuania, there have been determined the gradation of three levels of the territorial planning [3]: state level, municipality level, local territories. Each lower level of the territorial planning has to be guided by the approved decisions of the territorial planning provided by the higher level of 
the territorial planning by specifying them. In this way, the contradictions among the decisions of the different levels are prevented. The decisions made at the same level for the territorial planning documents have to be coordinated in between (with certain exceptions prescribed by the Law of Territorial Planning). Thus, the documents of the territorial planning are of two types: complex and special, the plans of land holdings are allocated to the planning documents of the land use. In the documents of the special territorial planning in terms of the territorial planning level and tasks there are determined the measures for certain activities dealing with the usage, administration and (or) protection of the planned territories [3]. The types of territorial planning documents are presented in figure 1.

From the scheme presented in Fig. 1, it is possible to make the decision about the variety of the special territorial planning documents, which help to ensure the implementation of the tasks of the special territorial planning, etc:

- to develop the conditions for a rational usage of the land, forests, subsoil resources and the use of cavities;

- to develop the systems of communications, engineering networks, energy systems and the other engineering structure required for the needs of the society and foresee the territories required for the development;

- to foresee the measures of protection of the landscape, nature and biological variety;

- to determine the heritage requirements for the boundaries of the territories and for the heritage protection in the complex objects of the immovable cultural heritage and their protection zones in the locations of the immovable cultural heritage activity development and protection;

- to determine the special conditions of the land usage [3].

However, due to the improperly executed monitoring of the territorial planning documents and publicizing in cyberspace, these tasks are only partly implemented practically therefore, when trying to more openly clarify the possible or restricted economical activities in the planned territory and the special plans are approved before the validation of the new edition of the Law on the Territorial Planning, the decisions of which have the mandatory legal power and remains mandatory till is completed the preparation of the replacement documents of the same level or lower level of the complex territorial planning documents.

When integrating the decisions of the special territorial planning documents it is required to eliminate the frequently occurring in practice the errors of planning, when the decisions of the same or lower level contradict the territorial planning documents of the same or higher level. The contradictions have to be eliminated by performing the complex analysis of the valid territorial planning documents during which the planner has to assess the real decisions of the projects from the point of view of the technologies, engineering, administrative and financial concepts. To prepare one professional having the competence in all the above mentioned fields or even a certain part of the competencies mentioned above is practically impossible, therefore, during the process of the territorial planning there have to participate the professionals of various competencies: architects, engineers (land use, geodesy and etc.), geographers, landscapers, environmentalists, economists, lawyers, sociologists, historians, archaeologists and psychologists. In order to strengthen the integrated planning and implementation, a great attention has to be given to the permanent training of professionals, skills improvements and education and information of the society [1], [6].

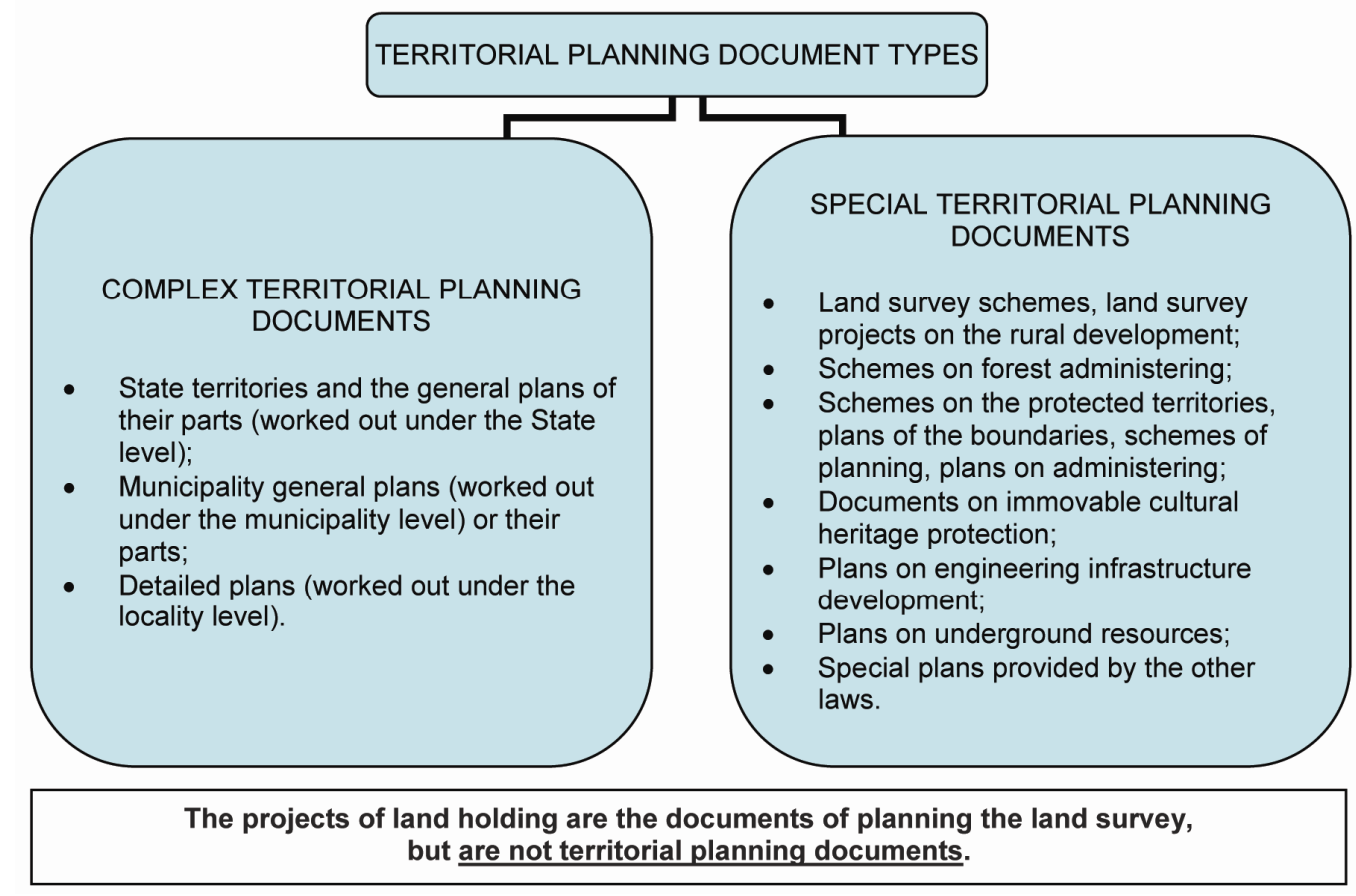

Fig. 1. Types of territorial planning documents 


\section{Interaction of land use planning and territorial planning}

Since January 1, 2014 separate agricultural parcels are formed, based not on the detailed plans, but on the projects of the land holdings. The decisions on the land holding could not object the decisions of the complex or special territorial planning documents, laws or other legal acts, therefore, the formation of the parcels and particular the activities on the parcel have to be implemented in accordance with the available current territorial planning documents. The manner of the land parcels formation prescribes both the analysed Law on Territorial Planning of the Republic of Lithuania and the Law on Land Reform of the Republic of Lithuania and the Law on Land of the Republic of Lithuania [5], [10].

The Law on Land prescribes that the project of land holding is the document of planning the land survey (Fig. 1), determining the order of formation of the land parcel (parcels), their rearrangement, taking over the public needs, consolidation, as well as conditions and terms of usage (purpose, restrictions, servitudes and etc.).

When working out the projects for land consolidation, parcel formation and parcel reconstruction, one of the tasks is to be able to determine the restrictions of the land usage, regulated by the legal acts or to eliminate the existing, but not relevant restrictions, to organize the required rural infrastructure, to perfect the recreational, rural tourism and esthetical resources, to implement the other goals of land, rural and environment policy. When implementing the challenges posed, there often appear uncertainties how properly determine special conditions of land usage, if the project organizes are not obliged to work out the topographic plan of the territory. The institutions, coordinating the projects, recommend, the working out of the project when special land use conditions have to be determined and to be guided by the sets of the state geo-referential spatial data, maps based on geo-referential data and the submitted data by the enterprises managing and (or) maintaining the engineering and communication infrastructure in the territory. It is important to apply the latest, extensive cartographic material, when determining the special land use conditions and restrictions. Therefore, the non-presented objects of the existing situation on the drawing of the cartographic background of the decisions of the object are submitted on the additional coordinated Raster images which supply the details of the cartographic background or justify the decisions.

Due to the mentioned above reasons for the implementation of the projects there are required to be collected the necessary initial material, but it takes a lot of time and efforts. The organiser of the designing works compiles the contract on the working out of the project and implementation, where there have to be indicated who is in charge of collecting the material on the project. Because of the great amount of the data presented by the suppliers and the inadequate publicizing of the territorial planning documents and availability on the cyberspace, the prescribed order does nor ensure the required quality of performing these activities. Thus, the quality of the land survey and territorial planning documents depend not only on the experience of the professionals working on the project and their skills but on the relevance and completeness of the used cartographic material for the project.

\section{Determining special conditions of land use on the cadastre of the real estate}

The cadastral data of the newly formed or renovated land parcels, the special conditions on land use included are registered on to the cadastre or registry of the real estate [5]. The data are presented after the cadastral measurements of the land parcels are made and the file of the cadastral data is prepared. The order of collecting the cadastral measurements and cadastral data is regulated by the Regulations of the Real estate of the Republic of Lithuania and the Rules on the Real Estate Cadastre Data Collecting and Adjustment.

There have to be used the following data for the cadastral measurements the projects of the land survey of the land reform and the copies of the fragments of the additional plans required for their preparation the copies of the detailed plans under the scales of M 1:500, M1:1000 and M 1:2000, the copies of the land survey projects and other special plans where the formed land parcels are located, the copies of the plans of the land parcels, the orthophoto maps and topographic maps compiled on their basis at al. [11-12].

When performing the cadastral measurements there were case when after investigating the territorial planning documents or the projects of the land holding and the performed works of mapping there were determined that the special conditions and restrictions of the land use there were not defined for the parcel or there were defined but not correctly. Due to these reasons, there could appear the difficulties in calculating and indicating the areas of the restrictions. The real threat could be regarding the quality of the cadastre data, because the restrictions of the land usage influence the value of the land parcel, and the taxable value. The incorrectly determined conditions and restrictions of the land use tend to cause the disputes with the owners of the adjacent parcels and various institutions, therefore, the uncertainties have to be eliminated. However, the cadastral data, entered into the registry of the real estate, containing the special conditions of land use and restrictions were considered to be correct and comprehensive till the time, they were contested by the order as prescribed by the laws [13], therefore, it was difficult to make amendments and correct the errors during the sequence of the territorial or land survey planning and at the moment of the real estate object formation. To change the special conditions entered on the registry of the real estate or determine the new ones was possible only after the approval of the new territorial planning document and its specifying. It required a lot of time, increased the costs of the preparation of the papers of the property ownership, therefore after the taking into effect the new edition of the Law on the Territorial Planning there were changed the other legal acts related with the law including the Law on Land.

After taking into effect the changes of the Law on Land there was simplified the order of the special conditions of the land use determining, there appeared the possibility to define the additional special conditions by the written approval of the 
owner of the land parcel, if necessary by the agreement concerning the compensation of the possible losses. In cases, when the special land use conditions applied to land parcel were not indicated and (or) entered into the data file of the Real Estate Cadastre or Registry, it is necessary to change the cadastral data of the land parcel. The procedure of entering these conditions into the Real Estate Cadastre and Registry is organized by the Executive Manager of the National Land Service in accordance with the laws prescribed by the provisions of the cadastre [5]. It has to be notified, that in the field of determining of the special conditions of the land and forest use there is a tendency for the positive changes. However, the determination of the additional terms of land use takes a long time, due to the need of the preparation of the required documents( because of the plan of the special terms and conditions of the use applicable to the land parcel, the form of the cadastral data, the statements of the calculation of the values) as well as because of their auditing, coordination of the information by the registered letters to the person concerned, because of the errors made and because of the disputes held.

The project of 2014 is the following: to perform the changes of the Law of the Cadastre of the Real Estate related to the data of the cadastre followed by the amendments of the legal acts of the by-laws. Firstly have to be changed the provisions of the law of the Real Estate Cadastre, the regulations of the real estate cadastre collecting and revising as well as the resolution of the Government of the Republic of Lithuania, dated May 12, 1992, resolution No. 343 'On the Approval of the Special terms and conditions of the land and forest use'. The process of determining of the special terms and conditions of the land and forest use is a complicated one, requiring not only the professional knowledge, but the competence of the majority of the regulating legal acts regarding the territorial planning, land survey, real estate cadastre, environmental protection and other fields.

\section{The supply of the data and the upgrading in the IT system}

The constantly improved geographic information system (GIS) directly influence the development of the geographic (spatial) data, which often used to solve the tasks of planning and forecasting currently [14]. On the other hand, the data have to be relevant and easy to get, otherwise the incorrect decision could be made.

The analysis of the legal acts related to the territorial planning in Lithuania indicate various ten sets of geographic (spatial) data, which have to be used during the process of planning of various territories. However, at present it is not enough to possess only the data stored on the Registry and Cadastre of the Real Estate of the Republic of Lithuania. Additionally, it is necessary to investigate more than ten data sources. These data sets are in different details and represent various stable natural and anthropogenic objects, information on the land usage, resources, natural or economical characteristics, protected territories and objects, etc. It must be recognized that the compiling of the datasets and the support of their relevance is a complicated process requiring many resources. The State finances the compiling of the majority of the required spatial datasets, but certain municipalities have limited possibilities to store the required spatial data according to the requirements. When investigating the spatial data sets financed by the State from the other approaches there were also determined the disadvantages influencing the particularity of the data. Even though, the latest data sources were available, the upgrading process tended to take a long time and the when the data were upgraded again they were already considered as 'outdated'. As an example could serve the compiling of the orthophotographic maps which takes about 1-2 years to compile it. They are used for updating the spatial data set of the georeference base of the Republic of Lithuania (GDR10LT). This process takes about 1-2 years as well. In another hand the spatial data set of special land use condition at a scale of 1:10,000 (SŽNS_DR10LT) is updated every half a year in accordance with the updated GDR10LT. The zones to be protected are usually applied for the rather immutable objects, therefore, it could be possible to derive the conclusion that the delayed upgrading of the data should not have a significant influence on the decisions made but such a probability might remain.

After the accomplishing the INSPIRE directive and the provisions of the Geodesy and Law on Cartography the majority of the spatial datasets required for the decision making mentioned in the article are available on the portal of the spatial information of Lithuania, which is based on the infrastructure of the spatial information (SDI) of Lithuania. The technologies implemented by SDI allow using effectively the accrued in various systems geographic data of Lithuania [1518 ] and providing the users in the acceptable form without taking into consideration the place of their storage, the structure and size [19]. Nevertheless, the technological possibilities are available for the easy access to the spatial data, but the geoportal of Lithuania is not a specified infrastructure for satisfying the whole process of planning. Therefore, in order to facilitate the accessibility of the required information for the participants of the territorial planning process, to automate and transfer onto the cyberspace the execution of the processes, related to the territorial planning and land survey, to ensure the transparency of the process of the working out of the documents, to perfect the management of these processes and to promote the participation of the public and business subjects in the decision making, there is developt the information system for working out the territorial planning documents (TPDRIS) and the information system for the working out of the land survey planning documents (ŽPDRIS) which are going to be compiled when integrating the functionality of SDI of Lithuania, provided for the review and administration of the spatial (geographic) information 


\section{Conclusions}

1. It is required to provide the engineering, social and communication infrastructure, natural and urban framework when working out the territorial planning documents and ensuring the implementation of the principals of the harmonious development.

2. It is necessary to take into consideration, when interrogating the valid decisions of the special plans into the general plan, the application of the decision binding and relevance; therefore, the clear criteria for the decision selection have to be formulated.

3. In order to simplify the administration of the process of the working out the land holding projects, to perfect the accessibility of the information for the participants working on the projects, it is required to speed up the compiling of the information system for working out the documents of the land survey planning (ŽPDRIS).

4. In order the tax system, regarding the real estate and land, to be used as the means, promoting the harmonious expansion of the rural territories and the development of the urban territories, it is necessary to work out the changes of the legal, normative and methodological documents, regulating the process of determining the cadastral data and entering of these documents into the Cadastre of the Real Estate and Registry and at the same time by simplifying the order the special terms and conditions of land use are determined, and by speeding up the working out of the property ownership documents and by reducing their costs.

\section{References}

[1] Juškevičius, P.; Burinskienè, M.; Paliulis, G. M.; Gaučè, K. 2013. Urbanistika: procesai, problemos, planavimas, plètra [Urbanism: processes, problems, planning, development]. Vilnius: Technika. 384 p. ISBN 978-609-457-429-0. http://dx.doi.org/10.3846/1447-S

[2] Lietuvos Respublikos aplinkos apsaugos istatymas [Law on Environmental Protection of the Republic of Lithuania], Valstybès žinios, 1992 , No 5-75.

[3] Lietuvos Respublikos nekilnojamojo turto kadastro nuostatai [Regulations of Real Property Cadastre of the Republic of Lithuania], Valstybės žinios, 2002, No 41-1539.

[4] Lietuvos Respublikos teritorijų planavimo įstatymas [Law on the Territorial Planning of the Republic of Lithuania], Valstybės žinios, 1995, No 1072391; 2004, No 21-617; 2013, No 76-3824.

[5] Lietuvos Respublikos žemès reformos istatymas [Law on the Land Reform of the Republic of Lithuania], Valstybès žinios, 1991, No 24-635; 1997, No 69-1735.

[6] Burinskienè, M.; Bardauskienè, D. 2012. Lietuvos 2007-2011 m. urbanistinių forumų veiklos apžvalga [Review of the activities of the urban forums of Lithuania for 2007-2011] VI Lietuvos urbanistinis forumas. Šiuolaikiški miestai ir miesteliai: situacija, vystymosi tendencijos, vizija, Vilnius, Lithuania, 2012. Vilnius: Technika, 54-57.

[7] Pakalnis, M.; Bardauskienė, D. 2012. Žalioji ir rudoji urbanistika, priešprieša ir sąlytis, konformistiniai sprendimai urbanistikoje [Green and brown urbanism, confrontation and contract, conformist decisions in urbanism] in VI Lietuvos urbanistinis forumas. Šiuolaikiški miestai ir miesteliai: situacija, vystymosi tendencijos, vizija, Vilnius, Lithuania, 2012. Vilnius: Technika, 8-13.

[8] Varnaite, D. 2012. Urbanistinio paveldo apsauga: nuo kritikos prie konstruktyvaus bendradarbiavimo [Protection of the urban heritage: from criticism towards constructive cooperation] VI Lietuvos urbanistinis forumas. Šiuolaikiški miestai ir miesteliai: situacija, vystymosi tendencijos, vizija, Vilnius, Lithuania, 2012. Vilnius: Technika, 18-23.

[9] Komarovska, A. 2013. The multicriteria assessment of the territory planning process: the investment aspect. Doctoral dissertation. Vilnius: Technika.

[10]Nekilnojamojo turto objektų kadastrinių matavimų ir kadastro duomenų surinkimo bei tikslinimo taisyklès [Rules for collection and revision of real property objects cadastral surveying and cadastral data], Valstybès žinios, 2003, No 18-790.

[11]Lietuvos Respublikos žemės įstatymas [Law on the Land of the Republic of Lithuania], Valstybès žinios, 1994, No 34-620; 2004, No 28-868

[12] Specialiosios žemès ir miško naudojimo sąlygos [Special conditions for land and forest use], Valstybès žinios, 1992 , No 22-652.

[13]Lietuvos Respublikos nekilnojamojo turto kadastro istatymas [Law on the Cadastre of the Real Estate of the Republic of Lithuania], Valstybès żinios, 2000, No 58-1704; 2003, Nr. 57-2530.

[14]Başaraner, M. 2002. Model Generalization in GIS, in Proc. of the International Symposium on GIS. September 23-26, 2002. Istanbul, Turkey.

[15]Lietuvos Respublikos geodezijos ir kartografijos įstatymas [Law on Geodesy and Cartography of the Republic of Lithuania], Valstybès žinios, 2001, No 62-2226; 2010, No 54-2649.

[16]Beconytė, G.; Paršeliūnas, E.; Pubellier, C. 2007. Sustainable development of the Lithuanian Geographic Information Infrastrukture, Ekologija [Ecology] 53: 22-26.

[17]Beconyte, G.; Pubellier, C. 2006. Geographic information infrastructure - towards interoperability of the public data, Geografija [Geography] 42(1): 23-27.

[18]Pubellier, C. 2005. Lithuanian Geographic Information Infrastructure - spatial data sharing with Lithuania, Geodezija ir kartografija [Geodesy and Cartography] 21(2): 47-53.

[19]Beconyte, G.; Papšienè, L.; Kryžanauskas, A. 2010. Lietuvos erdvinès informacijos sklaidos galimybès ir perspektyvos, Geodezija ir kartografija [Geodesy and Cartography] 36(2): 73-80 